\title{
Analisis Karakteristik Kecelakaan Lalu Lintas pada Jalan Yos Sudarso Kota Pekanbaru
}

\author{
Tomi Yandi, Fadrizal Lubis, Winayati \\ Program Studi Teknik Sipil-Fakultas Teknik \\ Universitas Lancang Kuning \\ E-mail: tomiyandi94@gmail.com,fadrizal@unilak.ac.id, winayati@unilak.ac.id
}

\begin{abstract}
Abstrak
Peningkatan jumlah penduduk di kota Pekanbaru menyebabkan peningkatan jumlah pergerakan dengan menggunakan kendaraan, Masalah arus lalu lintas yang sering terjadi menyebabkan macet, polusi udara,suara atau kebisingan dan kecelakaan. Masalah kecelakaan perlu dilakukan penelitian dengan tujuan untuk mengetahui karakteristik kecelakaan yang terjadi di Jalan Yos Sudarso Pekanbaru berdasarkan data tingkat kecelakaan yang terjadi pada tahun 2014-2018 sebanyak 73 kejadian kecelakaan dengan jumlah korban meninggal dunia 23 korban, luka berat 37 korban dan luka ringan 83 korban. Metode yang digunakan untuk penelitian ini menggunakan metode Angka Ekivalen Kecelakaan dan Cussum, dari hasil data kecelakaan menunjukan di ruas jalan Yos Sudarso Pekanbaru terdapat beberapa karakteristik kecelakaan selama periodetahun 2014-2018 yaitu berdasarkan hari kejadian sebanyak 33 korban yang terjadi kecelakaan pada hari minggu, berdasarkan waktu kejadian sebanyak 34 korban yang terjadi di pagi hari jam 06.00-12.00, berdasarkan tipe tabrakan sebanyak 53 korban dengan tabrakan depan belakang, berdasarkan jenis kendaraan sebanyak 84 korban menggunakan sepeda motor, berdasarkan kondisi korban sebanyak 83 korban dengan luka ringan, berdasarkan jenis kelamin 101 korban laki-laki, berdasarkan usia sebanyak 50 korban diusia 16- 30, berdasarkan faktor penyebab sebanyak 143 korban terjadi karena faktor manusia dan berdasarkan lokasi kejadian sebanyak 16 korban dititik STA $18+000$.
\end{abstract}

Kata Kunci : Karakteristik, Kecelakaaan, Lalu Lintas

\begin{abstract}
Increasing the number of residents in the city of Pekanbaru led to an increase in the number of movements using vehicles, traffic flow problems that often occur causing traffic jams, air pollution, noise or noise and accidents. The problem of accidents needs to be carried out research with the aim to determine the characteristics of accidents that occurred in Jalan Yos Sudarso Pekanbaru city based on data on accident rates that occurred in 2014-2018 as many as 73 accident events with 23 fatalities, 37 fatal injuries and 83 minor injuries victim. The method used for this study uses the Number Equivalent Accident and Cussum method. From the results of the accident data, there are several characteristics of accidents during the Yos Sudarso Pekanbaru road section for the period 2014-2018, which are based on the occurrence of 33 accidents on Sundays, based on there were 34 casualties that occurred in the morning at 06.00-12.00, based on the type of collision as many as 53 victims with a front rear collision, based on the type of vehicle as many

as 84 victims using motorbikes, based on the condition of 83 victims with minor injuries, based on sex 101 male victims, based on the age of 50 victims aged 16-30, based on causal factors as many as 143 victims occurred due to human factors and based on the location of the incident as many as 16 victims at the point of

STA $18+000$.
\end{abstract}

Keywords: Characteristics, Accident, Traffic

\section{PENDAHULUAN}

Jalan Yos Sudarso Pekanbaru terletak di Kecamatan Rumbai Pekanbaru. Jalan Yos Sudarso Pekanbaru memiliki Panjang Jalan \pm 22 KM yang menampung arus lalu lintas arah Pekanbaru menuju ke arah Medan atau sebaliknya. Ruas jalan ini melayani lalu lintas berat dan ringan seperti truk, bus, dan jenis kendaraan roda empat lainnya serta roda dua untuk angkutan jarak dekat. Pada jalan tersebut sering terjadi kecelakaan lalu lintas, hal ini disebabkan keadaan jalan di beberapa bagiannya sudah terjadi kerusakan, berlubang, maupun bergelombang, juga karena faktor lingkungan, kondisi kendaraan dan keadaan pengemudi. Dari data kecelakaan yang diperoleh dari selama kurun waktu 2014-2018 telah terjadi kecelakaan lalu lintas di sepanjang Jalan Yos Sudarso Pekanbaru sebanyak 73 kasus, dengan Jumlah korban 143 orang. (Sumber: Unit Lakalantas Polresta Pekanbaru, 2019). Dari kecelakaan yang terjadi 
perlu dilakukan upaya untuk meningkatkan keselamatan lalu lintas jalan raya.

\section{STUDI PUSTAKA}

a. Karakteristik Kecelakaaan

Data korban lalu lintas dilihat dari segi kerugian materil akibat kecelakaan adalah sangat penting untuk menganalisis kecelakaan dan penentuan konsekuensi total kecelakaan kendaraan bermotor. Dua kategori utama tingkat kematian yaitu traffic safety dan public health.

Traffic sefety adalah suatu ukuran yang menunjukkan bagaimana sistem atau kinerja jalan beroperasi yang diukur dari jumlah korban (mati) persatu kali perjalanan, dicatat kendaraan persatuan panjang jalan. Sedang public health adalah jumlah kematian perunit populasi penduduk (Warpani, S,P., 2001).

Menurut penelitian Siregar, M, B, Sembiring, I, S., (2014), Winayati, Lubis F., (2015), dan Pahlika, L, A., (2017) Karakteristik kecelakaan meliputi sebagai berikut :

a. Berdasarkan hari kejadian

b. Berdasarkan jam kejadian

c. Berdasarkan tipe tabrakan

d. Berdasarkan jenis kendaraan

e. Berdasarkan kondisi korban

f. Berdasarkan jenis kelamin

g. Berdasarkan usia korban

h. Berdasarkanpenyebab kecelakaan

i. Berdasarkan lokasi kecelakaan

b. Analisis Blackspot

Untuk mengidentifikasi lokasi rawan kecelakaan ada 2 metode yang digunakan, yaitu :

1) Metode Angka Ekivalen Kecelakaan

Metode ini digunakan untuk menganalisis titik kecelakaan tertinggi (Black spot) yang terjadi di daerah yang akan ditinjau. AEK adalah angka untuk pembobotan kelas kecelakaan. Perhitungan AEK terikat dengan tingkat fatalitas kecelakaan lalu lintas dan jumlah kejadian kecelakaan yang menyebabkan kerugian material.

$\mathrm{AEK}=12 \mathrm{MD}+3(\mathrm{LB}+\mathrm{LR})+\mathrm{K}$

Keterangan:

$\mathrm{MD} \quad=$ Korban meninggal

LB = Jumlah korban luka berat

LR = Jumlah korban luka ringan
$\mathrm{K}=$ Jumlah kejadian kecelakaan

2) Metode Cussum

Dalam metode Cussum, analisis untuk mengetahui daerah rawan kecelakaan dengan cara membagi panjang jalan menjadi per segmen. Kemudian mencari nilai mean dari data jumlah kecelakaan pada jalan yang ada di jalan Yos Sudarso Kota Pekabaru. Langkah selanjutnya adalah mengurangkan jumlah kecelakaan tiap tahun dengan nilai mean pada setiap segmensegmen jalan yang ditinjau. Dan mencari nilai cussum dengan cara menjumlahkan nilai hasil pengurangan pada tahun pertama dengan tahun selanjutnya.

Mencari nilai mean $(\mathrm{W})$

Perhitungan untuk mencari nilai mean dari data sekunder, yaitu sebagai berikut :

$\mathrm{W}=\sum X \mathrm{i}: \mathrm{LxT}$

Keterangan:

$\mathrm{W} \quad=$ Nilai mean

L = Jumlah stasioning

$\mathrm{T}=$ Periode waktu

$\sum \mathrm{Xi} \quad=$ Jumlah kecelakaan

Mencari Nilai Cussum Kecelakaan Tahun Pertama (S0)

Perhitungan untuk mencari nilai cussum kecelakaan tahun pertama adalah dengan mengurangi jumlah kecelakaan tiap tahun dengan nilai mean yaitu:

$\mathrm{S}_{0} \quad=(\mathrm{Xi}-\mathrm{W})$

Keterangan:

$\mathrm{W} \quad=$ Nilai mean

$\mathrm{S}_{0} \quad=$ Nilai Cussum tahun pertama

$\mathrm{Xi} \quad=$ Jumlah kecelakaan tiap tahun

Mencari Nilai Cussum Kecelakaan Tahun

Selanjutnya (S1)

Dalam mencari nilai cussum kecelakaan tahun selanjutnya adalah dengan menjumlahkan nilai cussum tahun pertama dengan hasil pengurangan jumlah kecelakaan dan nilai mean pada tahun selanjutnya yaitu:

$$
\begin{array}{ll}
\mathrm{S} & =\left[\mathrm{S}_{0}+(\mathrm{Xi}-\mathrm{W})\right] \\
\text { Keterangan: } & \\
\mathrm{S} & =\text { Nilai Cussum kecelakaan } \\
\mathrm{S}_{0} & =\text { Nilai Cussum kecelakaan tahun } \\
& \text { pertama } \\
\mathrm{W} & =\text { Nilai mean } \\
\mathrm{Xi} & =\text { Jumlah kecelakaan tiap tahun pertama }
\end{array}
$$




\section{METODOLOGI PENELITIAN}

Untuk menganalisa data penelitian perlukan penyusunan langkah-langkah kerja sesuai dengan bagan alir yang telah dibuat sebagai berikut:

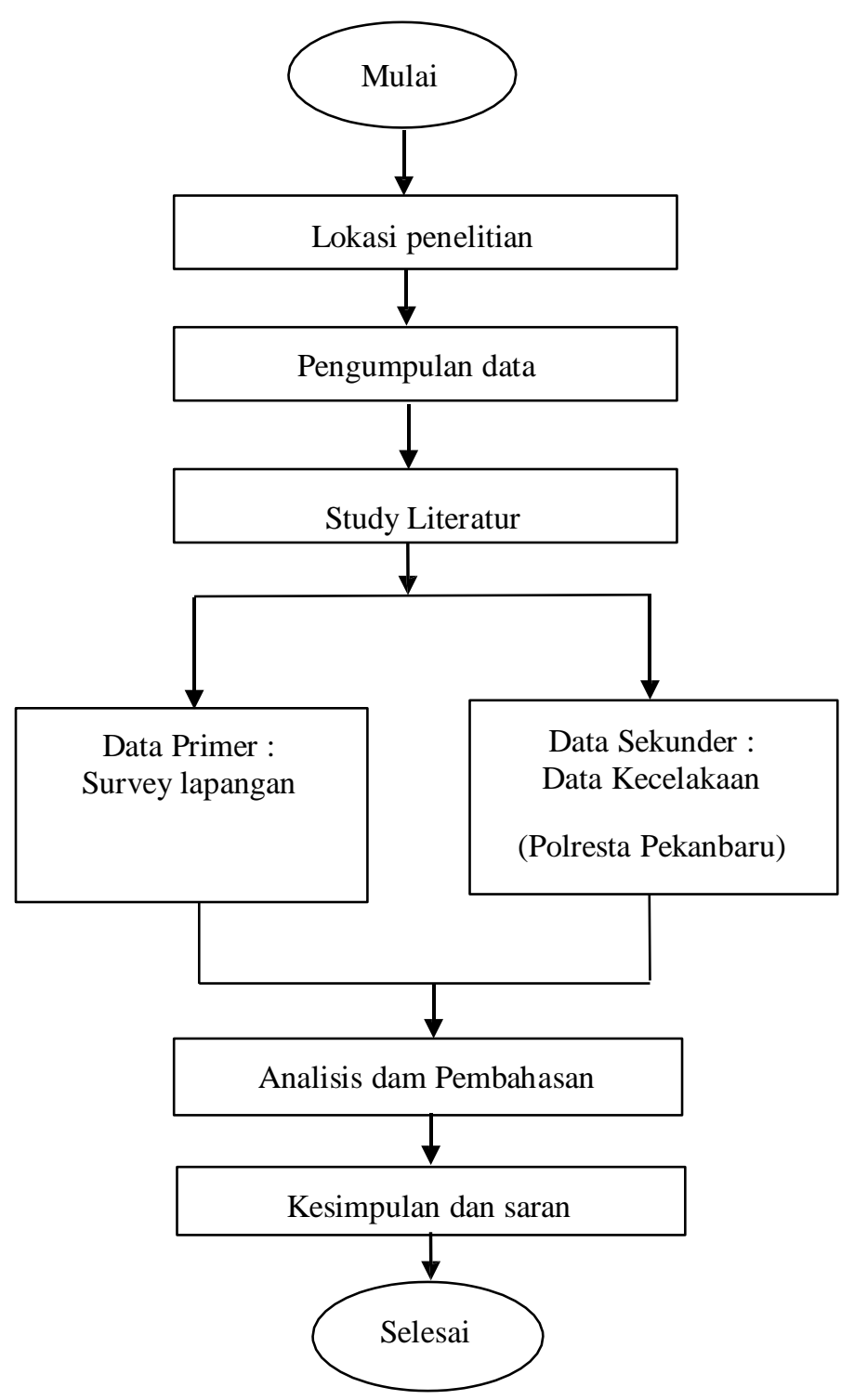

Gambar 1. Bagan Alir Penelitian (Sumber : Rencana Penelitian, 2019)

\section{HASIL DAN PEMBAHASAN}

1. Data kecelakaan

Tabel 1. Data Kecelakaan Lalu Lintas di Jalan Yos Sudarso Pekanbaru Periode 2014-2018

\begin{tabular}{|c|c|c|c|c|c|c|}
\hline \multirow{2}{*}{ No } & \multirow{2}{*}{ Thn } & \multirow{2}{*}{$\begin{array}{c}\text { Jmlh } \\
\text { Kec. }\end{array}$} & \multicolumn{3}{|c|}{ Korban } & \multirow{2}{*}{$\begin{array}{l}\text { Jmlh } \\
\text { Korban }\end{array}$} \\
\hline & & & LR & LB & MD & \\
\hline 1 & 2014 & 6 & 6 & 0 & 0 & 6 \\
\hline 2 & 2015 & 10 & 10 & 2 & 1 & 13 \\
\hline 3 & 2016 & 17 & 12 & 8 & 7 & 27 \\
\hline 4 & 2017 & 16 & 15 & 7 & 11 & 33 \\
\hline 5 & 2018 & 24 & 40 & 20 & 4 & 64 \\
\hline \multicolumn{2}{|c|}{ Jumlah } & 73 & 83 & 37 & 23 & 143 \\
\hline
\end{tabular}

(Sumber : Kasatlantas Polresta Pekanbaru, 2019)

\section{Karakteristik berdasarkan waktu kejadian}

a. Berdasarkan hari kejadian

Kecelakaan berdasarkan waktu kecelakaan berdasarkan hari kejadian kecelakaan di Jalan Yos Sudarso Pekanbaru periode 2014-2018 memiliki tingkat kecelakaan dan korban yang

tertinggi yaitu terjadi pada hari minggu terdapat 17 kejadian kecelakaan dengan korban 33 orang, diikuti hari senin 10 kejadian kecelakaan dengan 31 orang, hari jumat terdapat 10 kejadian dengan

27 orang, hari selasa 13 kejadian kecelakaan dengan 16 orang, hari kamis 10 kejadian kecelakaan dengan 16 orang, hari sabtu 8 kejadian kecelakaan dengan 10 orang, hari rabu 5 kejadian kecelakaan 10 orang.

b. Berdasarkan jam kejadian

Kecelakaan berdasarkan waktu kejadian dan jumlah korban di Jalan Yos Sudarso Pekanbaru selama periode 2014-2018 yang memiliki tingkat kecelakaan yang tertinggi yaitu terjadi pada pagi hari (06.00-12.00) terdapat 25 kejadian kecelakaan dengan 34 korban, sedangkan untuk korban yang tertinggi pada malam hari (18.00-00.00) terdapat 19 kejadian kecelakaan dengan 51 korban, pada siang hari (12.00-18.00) terdapat 23 kejadian kecelakaan dengan 50 korban, , dini hari (00.00-06.00) terdapat 6 kejadian kecelakaan dengan 8 korban.

3. Karakteristik berdasarkan tipe tabrakan

Karekteristik kecelakaan berdasarkan tipe tabrakan di Jalan Yos Sudarso Pekanbaru selama periode 2014-2018 yang meliputi tingkat kecelakaan dan korban paling tinggi yaitu terjadi pada tipe tabrakan depan belakang terdapat 32 
kejadian kecelakaan dengan 53 korban dan diikuti tipe tabrakan depan depan terdapat 19 kejadian kecelakaan dengan 33 korban, tabrakan depan menyudut terdapat 2 kejadian kecelakaan dengan 2 korban, tabrakan pejalan kaki terdapat 8 kejadiaan kecelakaan dengan 17 korban, tabrakan lepas control terdapat 6 kejadian kecelakaan dengan 15 korban, tabrakan parkir terdapat 1 kejadian kecelakaan dengan 1 korban, tabrakan beruntun 4 kejadian kecelakaan dengan 22 korban.

\section{Karakteristik berdasarkan jenis kendaraan}

Kecelakaan berdasarkan jenis kendaraan di Jalan Yos Sudarso Pekanbaru selama periode 2014-2018 kecelakaan tertinggi yaitu terjadi pada jenis kendaraan motor terdapat 84 kendaraan, diikuti dengan kendaraan mobil penumpang terdapat 33 kendaraan, kendaraan truck terdapat 22 kendaraan, dan kendaraan bus terdapat 2 kendaraan.

\section{Karakteristik berdasarkan kondisi korban}

Kecelakaan berdasarkan jenis kondisi korban di Jalan Yos Sudarso Pekanbaru selama periode 2014-2018 yang memiliki korban tertinggi yaitu korban luka ringan 83 korban, diikuti dengan korban luka berat terdapat 37 orang, korban meninggal dunia terdapat 23 korban.

\section{Karakteristik berdasarkan jenis kelamin}

Kecelakaan berdasarkan jenis kelamin di Jalan Yos Sudarso Pekanbaru selama periode 2014-2018 yang memiliki korban tertinggi pada laki-laki dengan 101 korban.

\section{Karakteristik berdasarkan usia}

Kecelakaan berdasarkan usia korban kecelakaan di Jalan Yos Sudarso Pekanbaru selama periode 2014-2018 yang memiliki korban tertinggi pada usia 16-30 tahun terdapat 50 korban.

\section{Karakteristik berdasarkan faktor penyebeb kecelakaan}

Kecelakaan berdasarkan faktor penyebab kecelakaan di Jalan Yos Sudarso Pekanbaru selama periode 2014-2018 yang paling dominan terjadi pada manusia akibat dari mendahului tidak dengan perhitungan, melakukan penyebrangan dan putar arah tanpa melihat situasi. Berdasarkan faktor penyebab ini memiliki 73 kejadian kecelakaan dengan 143 korban kecelakaan.

\section{Karakteristik berdasarkan lokasi kejadian}

Kecelakaan berdasarkan lokasi kejadian kecelakaan di Jalan Yos Sudarso Pekanbaru selama periode 2014-2018, titik rawan kecelakaan terjadi pada STA $1+000$ sampai STA 22+000, yang paling dominan terjadi pada STA $18+000$ terdapat 9 kejadian kecelakaan dengan 16 orang.

\section{Analisis Blackspot}

a. Metode Angka Ekivalen Kecelakaan

Dari perhitungan Angka Ekivalen

Kecelakaan tertinggi yaitu pada tahun 2018 dengan 252 Angka Ekivalen Kecelakaan, dan diikuti tahun 2017 dengan 214 Angka Ekivalen Kecelakaan, tahun 2016 dengan 161

Angka Ekivalen Kecelakaan, tahun 2015 dengan 58 Angka Ekivalen Kecelakaan, tahun 2014 dengan 24 Angka Ekivalen Kecelakaan.

b. Metode Cussum

Dari Perhitungan pada Jalan Yos Sudarso Pekanbaru KM 18 merupakan titik kecelakaan lalu lintas yang paling tinggi pada tahun 2014-2018 dengan nilai cussum sebesar 5,70.

\section{KESIMPULAN}

Berdasarkan analisis data yang telah dihitung, maka dapat diambil kesimpulan sebagai berikut :

1. Berdasarkan hari kejadian yaitu hari minggu sebesar 17 kejadian kecelakaan dengan 33 korban.

2. Berdasarkan waktu yaitu pada pagi hari jam 06.00-12.00 sebesar 25 kejadian kecelakaan dengan 34 korban.

3. Berdasarkan tipe tabrakan yaitu pada tipe depan belakang terdapat 32 kejadian kecelakaan dengan 53 korban.

4. Berdasarkan jenis kendaraan yaitu pada kendaraan bermotor terdapat 84 kendaraan.

5. Berdasarkan kondisi korban yaitu kondisi luka ringan (LR) sebesar 83 korban kecelakaan.

6. Berdasarkan jenis kelamin yaitu pada lakilaki sebesar 101 korban kecelakaan

7. Berdasarkan usia yaitu pada uisa 16-30 tahun sebesar 50 korban kecelakaan.

8. Berdasarkan penyebab yaitu pada manusia 73 kejadian kecelakaan dengan 143 korban.

9. Berdasarkan STA $18+000$ terdapat 9 kejadian kecelakaan dangan 16 korban kecelakaan.

10. Berdasarkan perhitungan metode AEK (Angka Ekivalen Kecelakaan), bahwa yang paling dominan terjadi kecelakaan yaitu pada tahun 2018 dengan hasil perhitungan 252 dari 24 kejadian kecelakaan.

11. Berdasarkan Perhitungan metode cussum, bahwa yang paling dominan terjadi kecelakaan yaitu pada tahun $2018 \mathrm{Km}$ $18+000$ dengan hasil perhitungan nilai cussum 5,70. 


\section{DAFTAR PUSTAKA}

Astarina, L, Sugiyanto, G, Indriyati, E, W., 2018, Analisis Karakteristik Kecelakaan dan Analisis Lokasi Black spot Di Kabupaten Bogor, Jurnal Dinamika Rekayasa, Vol.14 No.2, pp.65-74, ISSN :1858-3075.

Carina F, 2017, Analisis Karakteristik Kecelakaan Dan Penanganan Lokasi Rawan Kecelakaan Lalu Lintas Di Kota Lubuklinggau, Jurnal Bearing Penelitian dan Kajian Teknik Sipil, Vol.5 No.1, pp.24-31. ISSN :2085-6261.

Direktorat Jenderal Bina Marga, 1997, Manual Kapasitas Jalan Indonesia, No. 036/TBM/1997.

Direktorat Keselamatan Trasportasi Darat, 2006, Tentang Penyebab Kecelakaan Lalu Lintas.

Direktorat Jenderal Perhubungan Darat, Ditjen Hubdat, 2004, Cetak Biru Keselamatan Lalu Lintas dan Angkutan Jalan, Jakarta: Direktorat Lalu Lintas dan Angkutan Jalan, Direktorat Perhubungan Darat.

Ditjen Perhubungan Darat, 2007, Sosialisasi Keselamatan Lalu Lintas, No. 1210/AJ.403/DRJD/2007.

Djoko, S., 2003, Pengantar Rekayasa Dasar Transportasi, Perpustakaan UI, Jakarta.

Indriastuti, A, K, Fauziah, Y, Priyanto, E, 2014, Karakteristik Kecelakaan dan Audit Keselamatan Jalan Pada Ruas Ahmad Yani Surabaya, Jurnal Rekayasa Sipil, Vol.5 No.1, pp.40-50, ISSN :1978-5658.

Pahlika, L, A., 2017, Analisa Karakteristik Kecelakaan Lalu Lintas di Jalan Kaharuddin Nasution Pekanbaru, Tugas Akhir, Program Studi Teknik Sipil Universitas Lancang Kuning, Pekanbaru.
Peraturan Pemerintah Nomor 43 tahun 1993 Tentang Prasarana Lalu Lintas Jalan.

Putri, C, E., 2014, Analisis Karakteristik Kecelakaan dan Faktor Penyebab Kecelakaan Pada Loksi Black spot Di Kota Kayu Agung, Jurnal Teknik Sipil dan Lingkungan, Vol.2 No.1, pp.154-161, ISSN :2355-374X.

Siregar, M, B, Sembiring, I, S., 2014, Karakteristik Kecelakaan Lalu Lintas Studi Kasus: Jalan Nasional (Jalan Lintas Sumatera) Kabupaten Serdang Bedagai, Jurnal Teknik Sipil USU, Vol.3 No.3, pp.115, ISSN :2303-0127.

Undang-Undang Republik Indonesia Nomor 38 Tahun 2004 Tentang Jalan.

Undang-Undang Republik Indonesia Nomor 22 Tahun 2009 Tentang Lalu Lintas dan Angkutan Jalan.

Warpani, S,P., 2001, Rekayasa Lalu Lintas, Bharata, Jakarta.

Wedasana, A., 2011, Analisis Daerah Rawan Kecelakaan dan Penanganan Databese Berbasis Sistim Geografis Studi Kasus Kota Denpasar, Tesis, Jurusan Teknik Sipil, Bidang Kajian Utama Transportasi, Universitas Udayana, Denpasar.

Winayati, Lubis, F., 2015, Analisis Karakteristik Kejadian Kecelakaan Lalu Lintas Pada Ruas Jalan Yos Sudarso Kota Pekanbaru, Jurnal Siklus Teknik Sipil, Vol.1 No.1, pp.1-23, ISSN :2443-1729.

Yuwido, A., 2015, Tinjauan Karakteristik Kecelakaan di Jalan Yos Sudarso Rumbai Pekanbaru, Tugas Akhir, Program Studi Diploma Teknik Sipil Universitas Riau, Pekanbaru. 